\title{
Energy dissipation performance of the trapezoidal stepped spillway
}

DOI:10.36909/jer.13649

\author{
Erdinc Ikinciogullari* \\ Department of Civil Engineering, Bingol University, Bingol, 12000, Turkey. \\ *Email: erdincikinciogullari@gmail.com; Corresponding Author.
}

\begin{abstract}
Stepped spillways are a more effective type of spillway in energy dissipation than conventional chute channels. Therefore, the dimensions of the energy breaker at the downstream of the stepped spillways are lower. It is an alternative especially for the downstream pool that cannot be built in sufficient length due to the terrain conditions. In this study, the energy dissipation performance of the trapezoidal stepped spillways was investigated numerically by using Flow3D software. Four different models and three different discharges were utilized for this aim. According to the results, the trapezoidal stepped spillway is more effective up to $30 \%$ than classical stepped spillways in energy dissipation. The depth of the trapezoidal step and the bottom base length of the trapezoid significantly affected the energy dissipation rate for the trapezoidal stepped spillway.
\end{abstract}

Key words: computational fluid dynamics (CFD); energy dissipation rate; Flow3D; step geometry; Trapezoidal stepped spillway. 


\section{INTRODUCTION}

Stepped spillways are used as an alternative weir for more energy dissipation. Based on the literature, the first example of the stepped spillway is estimated as the Akarnania stepped spillway in Greece in 1300 BC (Chanson, 2000). The construction of the stepped spillway has become quite economical and practical after the progress of the roller-compacted concrete (RCC) technology (Frizell and Mefford, 1991).

Stepped spillways dissipate more flow energy on the discharge channel because the flow hits the steps. For this reason, stepped spillways are more economical than conventional chute channels on the cost of the downstream basin (Boes and Hager, 2003; Chanson, 1998; Frizell and Mefford, 1991; Rice and Kadavy, 1996). Besides, the cavitation risk decreases because the flow energy decreases along the stepped spillway (Chanson, 1993).

In stepped spillways, the nap flow regime occurs at low flow rates and the skimming flow regime occurs at high flow rates. It was first mentioned by Ohtsu \& Yasuda (Ohtsu and Yasuda, 1991) that there is a transition flow regime between the nap and skimming flow regimes. The transition flow regime is the type of flow regime that looks like neither the nap flow regime nor the skimming flow regime (Fig. 1). The transition regime is undesirable by the designers because of the large amount of vibration (Chanson, 1996).

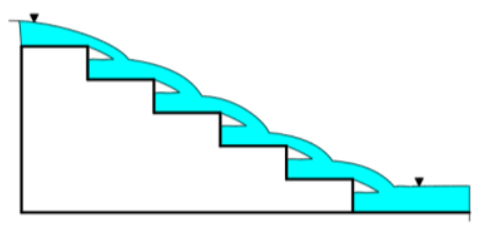

(a)

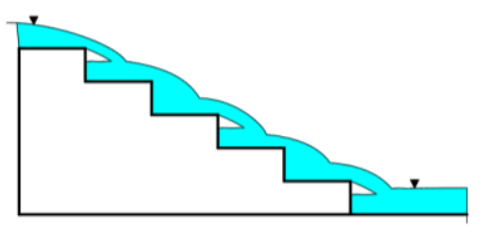

(b)

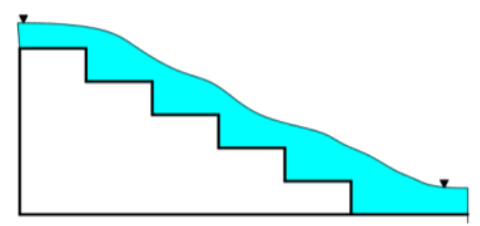

(c)

Figure 1 Flow regimes on the stepped spillway: a) nap flow regime; b) transition flow regime; c) skimming flow regime

According to the literature review, it was observed that the first period works were generally in the form of design principles (Boes and Hager, 2003; Chanson, 2001; Essery, I. T. S., \& Horner, 
1971; Sorensen, 1985). Felder et al. (2012a, 2012b) studied experimentally on the stepped spillway with different chute angles and different step configurations. According to the results, researchers emphasized that one of the most important criteria for residual energy is the chute angle. Zare and Doering (2012a, 2012b) experimentally investigated the inception points on the stepped spillway with different threshold configurations. They emphasized that the use of rounded steps dissipates $3 \%$ more energy than conventional steps.

Mero and Mitchell (2017) created five different stepped spillway models and experimentally examined the effect of step shapes on energy dissipation rates. The researchers created a different step geometry by placing reflectors on the steps. As a result of the study, they concluded that the energy dissipation rates of stepped spillways with reflectors are much higher than classical stepped spillways. The energy dissipation rate decreases as the discharge increases for all models.

The use of the Computational Fluid Dynamics (CFD) methods increases after the development of computer technology. Many researchers have analyzed the effect of different step geometries on energy dissipation rates numerically (Arjenaki et al., 2020; Ashoor and Riazi, 2019; Ghaderi et al., 2021, 2020; Hekmatzadeh et al., 2018; Li et al., 2020, 2018; Mohammad et al., 2016; Reeve et al., 2019; Shahheydari et al., 2015; Tabbara et al., 2005; Alkhamis et al. 2021). In this study, trapezoidal stepped spillways (TSS), which have not been studied in the literature, were analyzed numerically with Flow3D software. Different configurations were created to see the effect of TSSs on energy dissipation. The numerical results of the classical stepped spillway were validated by using the laboratory results (Mero and Mitchell, 2017). 


\section{MATERIAL AND METHOD}

\section{Numerical Model}

Flow $3 \mathrm{D}^{\circledR}$ software is a general-purpose CFD software that can be used to solve fluid problems [28]. This software can calculate the problem using the general mass equations and the Reynolds-Averaged Navier Stokes equations (RANS). These equations are shown in Eqs. (1 and 2).

$$
\begin{aligned}
& \frac{\partial U_{i}}{\partial x_{i}}=0 \\
& \frac{\partial U_{i}}{\partial t}+U_{j} \frac{\partial U_{i}}{\partial x_{j}}=-\frac{1}{\rho} \frac{\partial p}{\partial x_{i}}+\frac{\partial}{\partial x_{i}}\left(v \frac{\partial U_{i}}{\partial x_{j}}-\overline{u_{\imath}^{\prime} u_{j}^{\prime}}\right)+S_{i}
\end{aligned}
$$

here, $U_{i}=$ Reynolds average velocity, $x_{i}=$ location, $S=$ source term, t=time term $\rho=$ density of the fluid, $p=$ Reynolds average pressure, and $v=$ kinematic viscosity.

Flow3 $\mathrm{D}^{\circledR}$ software utilizes the volume of fluid (VOF) method for modeling of the free surface. The VOF method is described as Eq. 3.

$\frac{\partial F}{\partial t}+\frac{1}{V_{f}}+\left(\frac{\partial}{\partial x}\left(F u A_{x}\right)+\frac{\partial}{\partial y}\left(F v A_{y}\right)+\frac{\partial}{\partial z}\left(F w A_{z}\right)\right)$

here $A=$ average flow field, $F$ is the fraction function value between zero and one (0-1). As the value of the $F$ is 0 , this means that the cell is empty. When the $F$ is 1 , the cell is full (Flow Science Incorporated, 2016).

\section{Geometric model}

The experimental results of the classical stepped spillway designed by Mero and Mitchell (2017) were utilized to validate the numerical results. The classical stepped spillway was designed with a width of $0.296 \mathrm{~m}$, a height of $0.25 \mathrm{~m}$, and a base width of $0.50 \mathrm{~m}$. A total of five steps were designed as the step height is $0.05 \mathrm{~m}$, the step length is $0.10 \mathrm{~m}$, and the angle of the discharge channel is $26.6^{\circ}$ (Fig. 2). 


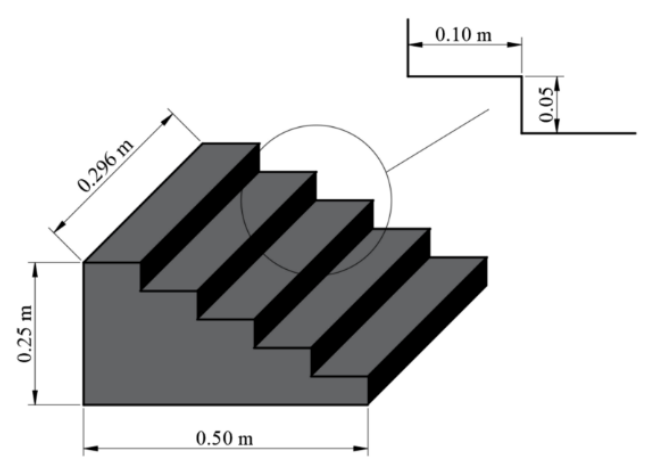

Figure 2 The model geometry designed by Mero and Mitchell (2017)

Four different TSS models were designed for the scope of the study. These models designed with the Solidworks program were saved as .stl extension and transferred to Flow3D software. $l_{r}$ is the depth of the trapezoidal step and $l_{1}$ is the bottom base length of the trapezoid in Fig. 3. Three different discharges $\left(0.0121-0.00831-0.00684 \mathrm{~m}^{3} / \mathrm{s}\right)$ and four different trapezoidal geometries $\left(l_{r}=0.01-0.03 \mathrm{~m}\right.$ and $\left.l_{1}=0.03-0.05 \mathrm{~m}\right)$ were utilized for numerical analyses. The flow regimes were determined according to the literature (Boes and Hager, 2003). The hydraulic characteristics of the study were summed up in Table 1.

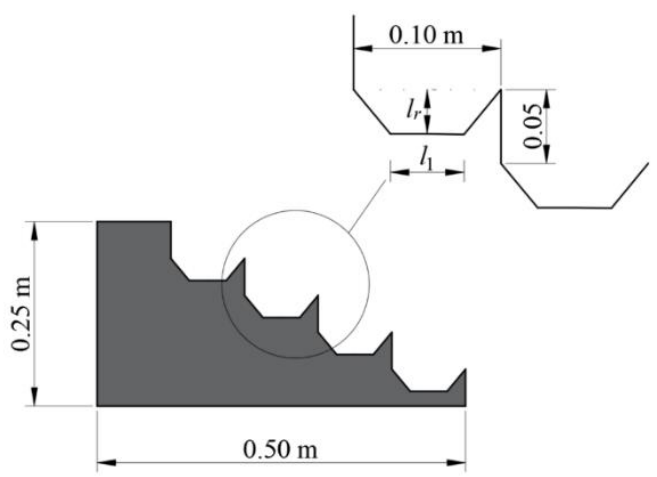

(a)

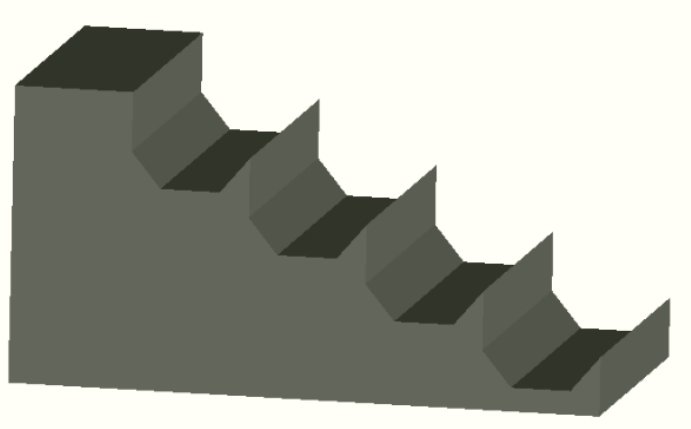

(b)

Figure 3 The design of the TSS; a) two-dimensional, b) three-dimensional 
Table 1 Hydraulic characteristics

\begin{tabular}{cccccccc}
$\begin{array}{c}\text { Analyze } \\
\text { No }\end{array}$ & $\begin{array}{c}\text { Model } \\
\text { No }\end{array}$ & $\begin{array}{c}\boldsymbol{Q} \\
\left(\mathbf{m}^{\mathbf{3}} \cdot \mathbf{s}^{-\mathbf{1}}\right)\end{array}$ & $\begin{array}{c}\text { Step } \\
\text { height } \\
(\boldsymbol{h})(\mathbf{m})\end{array}$ & $\begin{array}{c}\text { Step length } \\
(\boldsymbol{l})(\mathbf{m})\end{array}$ & $\begin{array}{c}\boldsymbol{l}_{\boldsymbol{r}} \\
(\mathbf{m})\end{array}$ & $\begin{array}{c}\boldsymbol{l}_{\mathbf{1}} \\
(\mathbf{m})\end{array}$ & $\begin{array}{c}\text { Flow } \\
\text { regime }\end{array}$ \\
\hline \hline 1 & Model1 & 0.01210 & 0.05 & 0.10 & 0.01 & 0.05 & Skimming \\
2 & Model1 & 0.00831 & 0.05 & 0.10 & 0.01 & 0.05 & Skimming \\
3 & Model1 & 0.00684 & 0.05 & 0.10 & 0.01 & 0.05 & Transition \\
4 & Model2 & 0.01210 & 0.05 & 0.10 & 0.03 & 0.05 & Skimming \\
5 & Model2 & 0.00831 & 0.05 & 0.10 & 0.03 & 0.05 & Skimming \\
6 & Model2 & 0.00684 & 0.05 & 0.10 & 0.03 & 0.05 & Transition \\
7 & Model3 & 0.01210 & 0.05 & 0.10 & 0.01 & 0.03 & Skimming \\
8 & Model3 & 0.00831 & 0.05 & 0.10 & 0.01 & 0.03 & Skimming \\
9 & Model3 & 0.00684 & 0.05 & 0.10 & 0.01 & 0.03 & Transition \\
10 & Model4 & 0.01210 & 0.05 & 0.10 & 0.03 & 0.03 & Skimming \\
11 & Mode14 & 0.00831 & 0.05 & 0.10 & 0.03 & 0.03 & Skimming \\
12 & Mode14 & 0.00684 & 0.05 & 0.10 & 0.03 & 0.03 & Transition \\
\hline \hline
\end{tabular}

\section{Energy dissipation rate}

The energy at the upstream and downstream of the spillway were used to calculate the energy dissipation rate. In the experimental study (Mero and Mitchell, 2017), the energy was calculated using the critical flow depth. Since the channel is rectangular, it can be calculated with Eq. (4) for the critical flow depth. The energies at (0) and (1) points as shown in Fig. 4 were calculated with Eqs. $(5,6)$. Then, the energy difference between the two points is calculated with Eq. (7).

$$
\begin{aligned}
& q=\frac{Q}{B} \quad \text { ve } \quad y_{c}=\sqrt[3]{\frac{q^{2}}{g}} \\
& E_{0}=H_{d a m}+y_{c}+\frac{V_{c}{ }^{2}}{2 g}=H_{d a m}+1,50 y_{c} \\
& E_{1}=y_{1}+\frac{V_{1}^{2}}{2 g} \\
& E_{L}=E_{0}-E_{1}
\end{aligned}
$$

here, $y_{c}=$ critical flow depth $(\mathrm{m}), Q=$ discharge $\left(\mathrm{m}^{3} / \mathrm{s}\right), q=$ unit flow rate $\left(\mathrm{m}^{3} / \mathrm{s} . \mathrm{m}\right), B=$ channel width $(\mathrm{m}), g=$ gravitational acceleration $\left(\mathrm{m} / \mathrm{s}^{2}\right), E_{0}=$ energy at $(0)$ point $(\mathrm{m}) ; H_{\text {dam }}=$ spillway height $(\mathrm{m}) ; y_{1}=$ flow depth at the downstream of the spillway $(\mathrm{m}) ; V_{c}=$ critical flow velocity $(\mathrm{m} / \mathrm{s})$ 
$V_{1}=$ flow velocity at $(1)$ point $(\mathrm{m} / \mathrm{s}) ; E_{1}=$ energy height at the downstream of the spillway $(\mathrm{m})$, and $E_{L}=$ energy difference between (0) and (1) points (m).

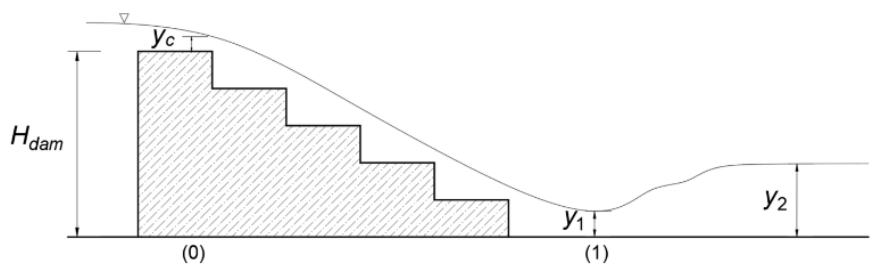

Figure 4 Longitudinal section of spillway

\section{Mesh Domain, boundary conditions, and verification}

A mesh block was used to design the domain of the trapezoidal model. Fourteen extra solution layers were placed inside this solution domain (Fig. 5a). Four different mesh domains were tried to find the correct mesh sizes. First, the total number of cells was selected as 198198 . Then, the

total number of cells was increased to 353925, 421008, and 662480, respectively. According to the obtained results, it was observed that after the total number of cells exceeds 400000 , there was not much effect on the results (Fig. 5b). For this reason, the mesh domain that the biggest cell size was $1.27 \mathrm{~cm}$, the smallest cell size was $0.50 \mathrm{~cm}$, and the total cell number was 421008 was sufficient for the study (Table 2).

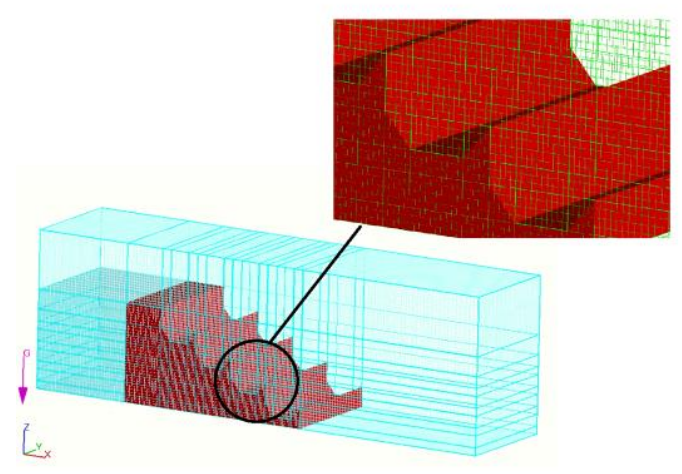

(a)

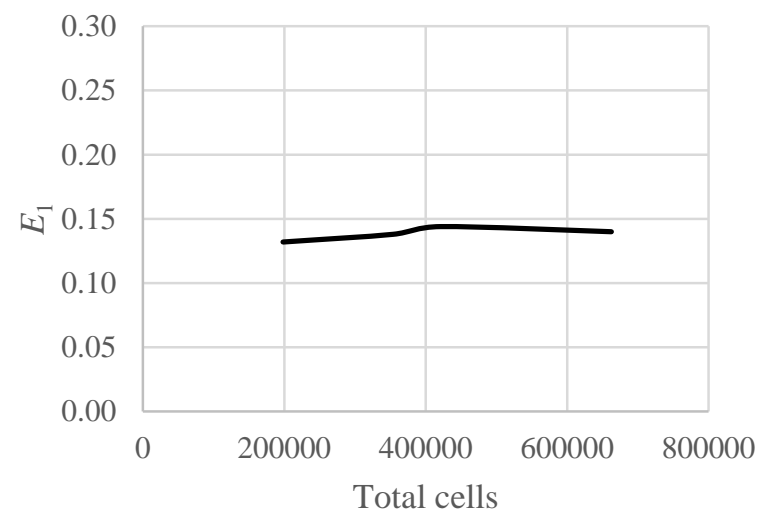

(b)

Figure 5 a) Mesh domain structure and b) Mesh independency 
Table 2 Mesh domain characteristics

\begin{tabular}{ccc}
$\begin{array}{c}\text { Mesh domain sizes } \\
\text { (Max.-Min.) } \\
(\mathbf{c m})\end{array}$ & $\begin{array}{c}\text { Total mesh } \\
\text { number }\end{array}$ & $\begin{array}{c}\boldsymbol{E}_{\mathbf{1}} \\
(\mathbf{m})\end{array}$ \\
\hline \hline $1.00-0.80$ & 198,198 & 0.132 \\
$0.94-0.67$ & 353,925 & 0.138 \\
$1.27-0.50$ & 421,008 & 0.144 \\
$1.30-0.35$ & 662,480 & 0.140 \\
\hline \hline
\end{tabular}

All boundary conditions have been designed according to the experimental conditions (Mero and Mitchell, 2017). The discharge boundary condition (Q) was utilized at the upstream of the channel. The outflow condition $(\mathrm{O})$ was used at the channel downstream. Furthermore, the channel bed and the walls were defined as the wall boundary condition (W). The upper plate of the channel was defined as the symmetry boundary condition $(\mathrm{S})$. A flow region $(0.25 \mathrm{~m}$ depth and $0.296 \mathrm{~m}$ width) has been defined at the spillway upstream (Fig. 6).

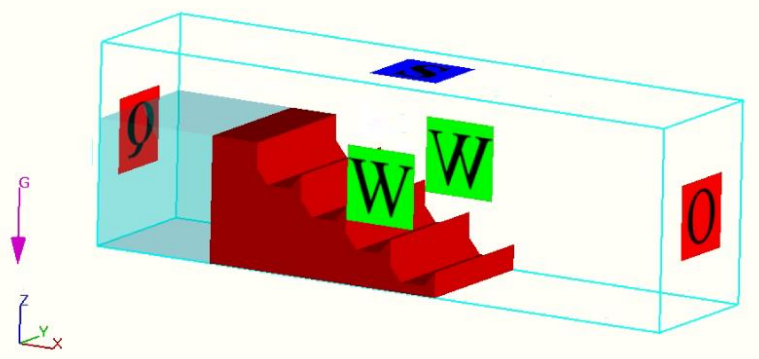

Figure 6 Boundary conditions

\section{Validation of the numerical model}

As mentioned above, the numerical results were validated with the experimental results (Mero and Mitchell, 2017). The numerical results using the RNG-k-e and Standard k-e turbulence models are shown in Fig. 7. It was observed that both turbulence models were compatible with the experimental results (Mero and Mitchell, 2017), but the error rates increase at maximum flow rates. Deviations in these values might result from rounding errors in numerical iterations or from readings in test results. The standard k-e model is more converged than RNG k-e. Therefore, the standard k-e turbulence model is more suitable for this study. 


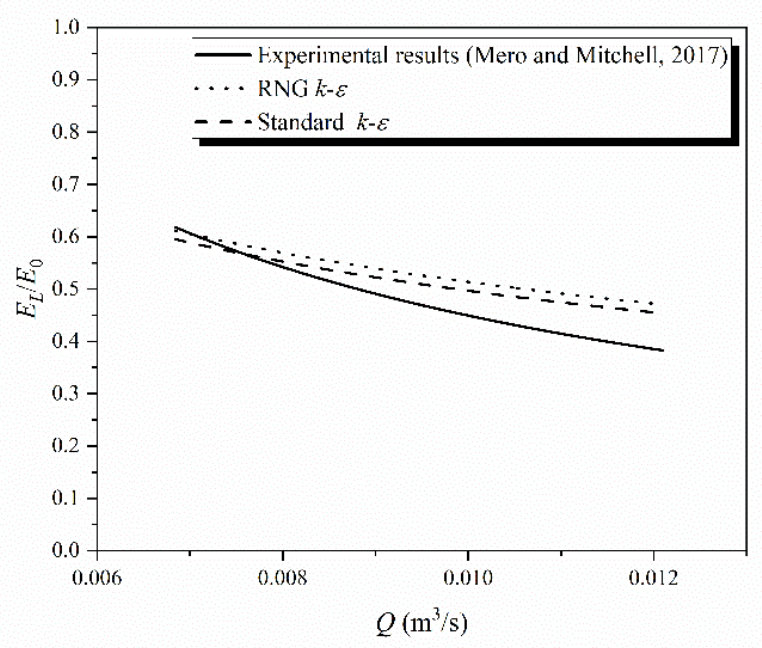

Figure 7 Convergence of the numerical results

\section{RESULTS AND DISCUSSION}

Spillways are water structures that transfer the flow from the upstream to the downstream. It is known that the flow velocity at downstream of spillways is higher due to the kinetic energy. For this reason, the designers use stepped weirs to reduce the costs of the energy breaker pool. In this study, a new type of stepped spillway has been designed by trapezoidal shape steps. The results of the study have been supported using velocity vectors plotted in a vertical transverse section; velocity and pressure distribution; total hydraulic head, and energy dissipation graph. As shown in Fig. 8, the three-dimensional velocity profiles on the TSS were designed for the skimming flow regime $\left(Q=0.0121 \mathrm{~m}^{3} / \mathrm{s}\right)$. The TSSs had low velocity than the classical stepped spillway. Besides, as the $l_{r}$ increases, the flow velocity at the downstream of the spillway decreases. Besides, it was observed that the TSSs dissipate more flow turbulence. Also, the fluctuations in the flow surface of the trapezoidal spillways did not observe in classical stepped spillways. It is thought that more air enters the flow due to the step geometry of the TSS. The same situation has been encountered in the literature studies (Arjenaki et al., 2020; Felder et al., 2012b; Ghaderi et al., 2020) for different step geometries. 


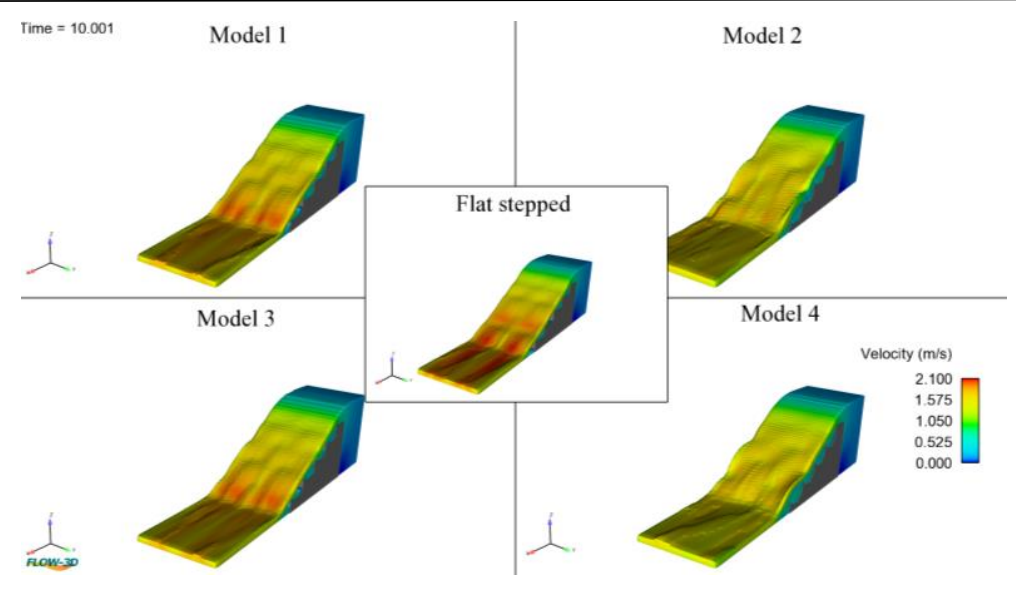

Figure 8 Three-dimensional velocity profiles for skimming flow regime

Figure 9 shows a comparison of the velocity contours at the TSSs. The highest velocity magnitude recorded in the overlying flow above the step edge and the smallest velocity value towards the bottom. For all models, the flow was confined in the recirculation zones under the pseudo bottom. The trapezoidal models' steps, on the other hand, have a greater amount of vortex flow.

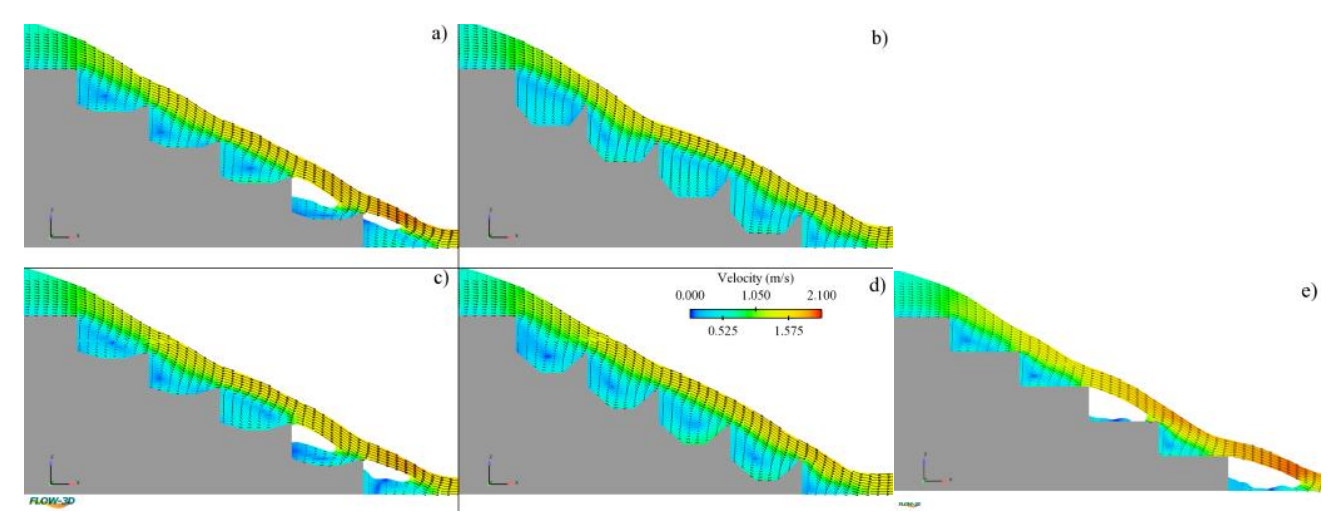

Figure 9 Velocity vectors of models: a) Model 1, b) Model 2, c) Model 3,

d) Model 4, and e) Classical stepped

For all models, the pressure variations were shown in Fig. 10. At the start of the steps, a low-pressure value was noticed. The highest pressure value, on the other hand, was found near the conclusion of the TSSs' steps. At the stages of the models, there was never a negative pressure value. As a result, the TSSs do not exhibit the cavitation phenomena. 


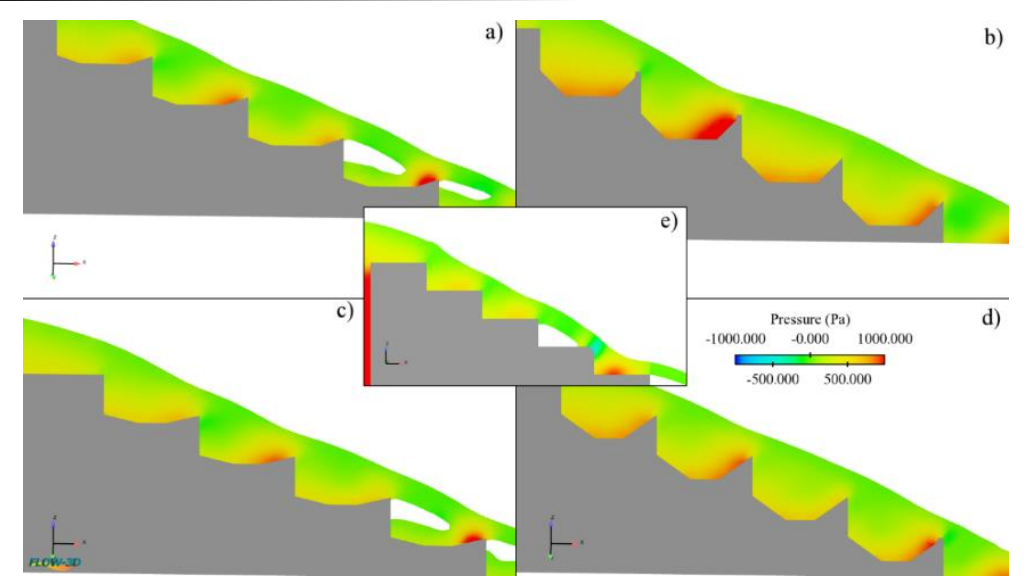

Figure 10 Pressure contours of models: a) Model 1, b) Model 2, c) Model 3,

d) Model 4, and e) Classical stepped

Figure 11 shows the three-dimensional simulation output of the total hydraulic head for all models (for $Q=0.0121 \mathrm{~m} 3 / \mathrm{s}$ ). The total energy at downstream of the classical stepped spillway is more than those of the TSS. To compare the energy head of the TSSs, the total hydraulic head

on the transverse section of the models is shown in Fig. 12 (at the tenth seconds). Hence, it was observed that the total energy head at the downstream of the spillways was decreased with increasing $l_{r}$ and $l_{1}$.

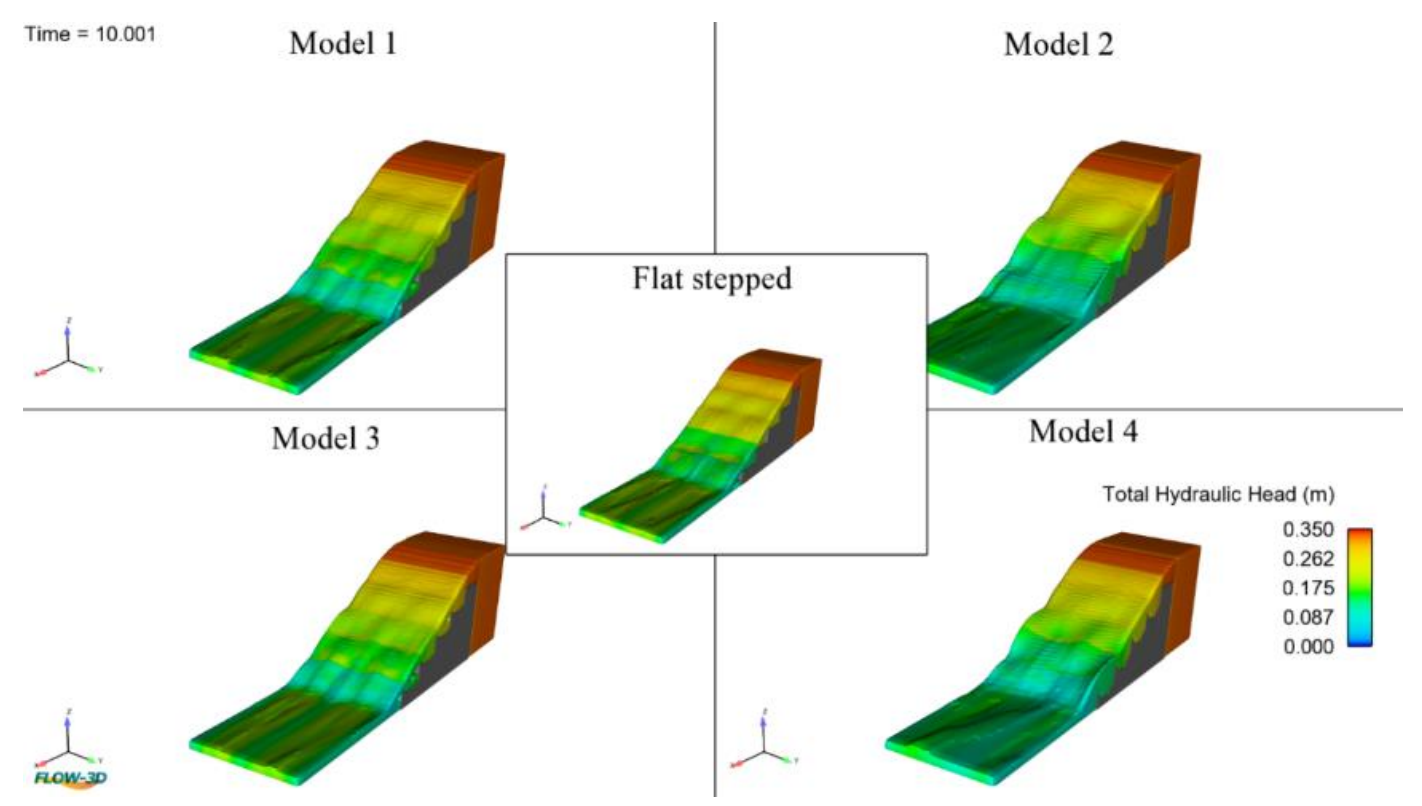

Figure 11 Three-dimensional total hydraulic head of the models 


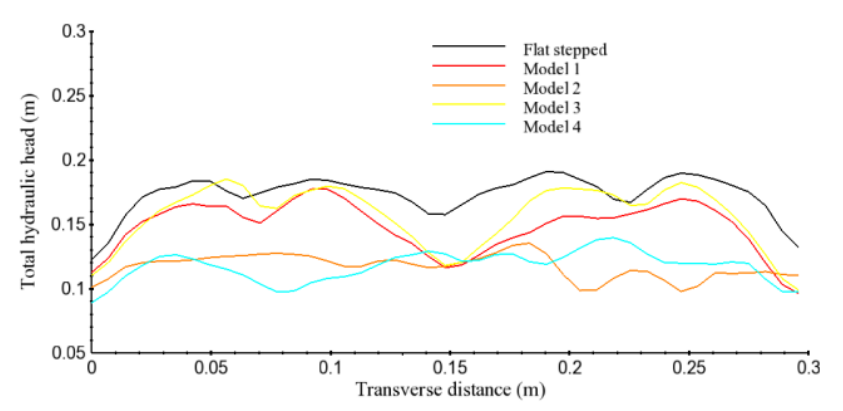

Figure 12. The total hydraulic head of the models on the transverse section

The energy dissipation rates of all models used in this study were illustrated in Fig. 13 as a function of the dimensionless critical flow depth $\left(y_{c} / h\right)$. According to the results, the TSSs are generally more efficient than the classical stepped spillway for energy dissipation. In the models designed as $l_{r}=0.01 \mathrm{~m}$, the energy dissipation rate of the TSS is lower than those of the flatted stepped spillway for the transition flow regime. However, in the models designed as $l_{r}=0,03 \mathrm{~m}$, the energy dissipation rate of the TSS is higher than those of the classical stepped spillway for the transition flow regime. Model 2 that designed with $l_{r}=0.03 \mathrm{~m}$ and $l_{1}=0.05 \mathrm{~m}$ was the most effective energy dissipator and this model dissipates more energy than the flat stepped spillway up to $30 \%$. Then, Model 4 was the second one for the energy dissipation rate. According to the results, $l_{r}$ and $l_{1}$ affected the energy dissipation rate for the TSS. As the $l_{r}$ and $l_{1}$ increased, the energy dissipation rate increased for both flow regimes. However, it was observed that the $l_{r}$ was more effective than the $l_{1}$ for energy dissipation rate.

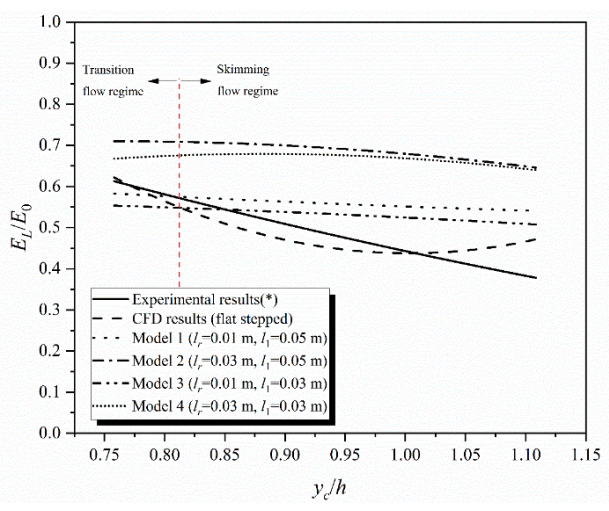

Figure 13 Comparison of the energy dissipation rate of the used models (*) Mero and Mitchell, 2017 


\section{CONCLUSION}

The energy dissipation performance of the trapezoidal stepped spillways (TSS) was investigated numerically by using Flow3D software. A total of 12 analyses were conducted for four different trapezoidal models and three discharges. The laboratory results conducted by Mero and Mitchell (2017) were used to validate numerical results on the classical stepped spillway. The results of the study were stated below:

- As the discharge increased, the energy dissipation rate decreased. This situation is in good agreement with the literature.

- The depth of the trapezoidal step $\left(l_{r}\right)$ and the bottom base length of the trapezoid $\left(l_{1}\right)$ affected the energy dissipation performance of the TSS. The energy dissipation rate increased as $l_{r}$ and $l_{1}$ increased. However, $l_{r}$ was more efficient than $l_{1}$.

- There was no cavitation phenomenon for TSS due to the high-pressure value on the steps.

- The recirculation regions occurred under the pseudo bottom for all models but there is vortex flow on the steps of the trapezoidal models.

- The TSS was more efficient than the classical stepped spillway up to $30 \%$ for energy dissipation.

- The amount of concrete for TSSs is low than the classical stepped spillway. However, the cost of the labor of TSSs is higher than the classical stepped spillways and the construction of these steps is difficult and time consuming.

- These structures might be used for downstream area restricted terrain conditions or in chute channels that structured in touristic areas for a stylish design.

\section{ACKNOWLEDGEMENTS}

The author thanks Firat University (Turkey) for use of the Solidworks and Flow3D ${ }^{\circledR}$ software. 


\section{REFERENCES}

Alkhamis, M., Sabbagh-Yazdi, S., R. and Ranjbar-Malekshah, M., 2021. Numerical evaluation of discharge coefficient and energy dissipation of flow over a stepped bell moth spillway. Journal of Engineering Research, 9(2).

Arjenaki, M.O., Hamed, ·, Sanayei, R.Z., 2020. Numerical investigation of energy dissipation rate in stepped spillways with lateral slopes using experimental model development approach. Model. Earth Syst. Environ. 6, 605-616. https://doi.org/10.1007/s40808-020-00714-z

Ashoor, A., Riazi, A., 2019. Stepped Spillways and Energy Dissipation: A Non-Uniform Step Length Approach. Appl. Sci. 9, 5071. https://doi.org/10.3390/app9235071

Boes, R.M., Hager, W.H., 2003. Hydraulic Design of Stepped Spillways. J. Hydraul. Eng. 129, 671679. https://doi.org/10.1061/(asce)0733-9429(2003)129:9(671)

Chanson, 2001. Hydraulic Design of Stepped Spillways and Downstream Energy Dissipators [WWW Document]. Dam Eng.

Chanson, 2000. Forum article. Hydraulics of Stepped Spillways: Current Status. Jl Hyd. Engrg., ASCE 126.

Chanson, 1998. Review of studies on stepped channel flows. Work. Flow Charact. around Hydraul. Struct. River Environ. 25.

Chanson, 1996. Prediction of the transition nappe/skimming flow on a stepped channel. J. Hydraul. Res. 34, 421-429. https://doi.org/10.1080/00221689609498490

Chanson, 1993. Stepped spillway flows and air entrainment. Can. J. Civ. Eng. 20, 422-435. https://doi.org/10.1139/193-057

Essery, I. T. S., \& Horner, M.W., 1971. The Hydraulic Design of Stepped Spillways [WWW Document]. Constr. Ind. Res. Inf. Assoc.

Felder, S., Fromm, C., Chanson, H., 2012a. The University Of Queensland Report Ch86/12 Air Entrainment And Energy Dissipation On A $8.9^{\circ}$ Slope Stepped Spillway With Flat And Pooled Steps School Of Civil Engineering.

Felder, S., Guenther, P., Chanson, H., 2012b. The University of Queensland Report CH87/12 AirWater Flow Properties And Energy Dissipation On Stepped Spillways: A Physical Study Of Several Pooled Stepped Configurations. School of Civil Engineering.

Flow Science Incorporated, 2016. FLOW-3D Users Manual.

Frizell, K.H., Mefford, B.W., 1991. Designing Spillways to Prevent Cavitation Damage. Concr. Int. $13,58-64$.

Ghaderi, A., Abbasi, S., Abraham, J., Azamathulla, H.M., 2020. Efficiency of Trapezoidal Labyrinth Shaped stepped spillways. Flow Meas. Instrum. 72, 101711. https://doi.org/10.1016/j.flowmeasinst.2020.101711 
Ghaderi, A., Abbasi, S., Di Francesco, S., 2021. Numerical Study on the Hydraulic Properties of Flow over Different Pooled Stepped Spillways. Water 13, 710. https://doi.org/10.3390/w13050710

Li, S., Yang, J., Li, Q., 2020. Numerical Modelling of Air-Water Flows over a Stepped Spillway with Chamfers and Cavity Blockages. KSCE J. Civ. Eng. 24, 99-109. https://doi.org/10.1007/s12205020-1115-x

Li, S., Zhang, J., Xu, W., 2018. Numerical investigation of air-water flow properties over steep flat and pooled stepped spillways. J. Hydraul. Res. 56, 1-14. https://doi.org/10.1080/00221686.2017.1286393

Mero, S., Mitchell, S., 2017. Investigation of energy dissipation and flow regime over various forms of stepped spillways. Water Environ. J. 31, 127-137. https://doi.org/10.1111/wej.12224

Mohammad, M., Tabari, R., Tavakoli, S., 2016. Effects of Stepped Spillway Geometry on Flow Pattern and Energy Dissipation. Arab J Sci Eng 41, 1215-1224. https://doi.org/10.1007/s13369015-1874-8

Ohtsu, I., Yasuda, Y., 1991. Transition from supercritical to subcritical flow at an abrupt drop. J. Hydraul. Res. 29, 309-328. https://doi.org/10.1080/00221689109498436

Reeve, D.E., Zuhaira, A.A., Karunarathna, H., 2019. Computational investigation of hydraulic performance variation with geometry in gabion stepped spillways. Water Sci. Eng. 12, 62-72. https://doi.org/10.1016/j.wse.2019.04.002

Rice, C.E., Kadavy, K.C., 1996. Model Study of a Roller Compacted Concrete Stepped Spillway. J. Hydraul. Eng. 122, 292-297. https://doi.org/10.1061/(asce)0733-9429(1996)122:6(292)

Shahheydari, H., Nodoshan, J., Barati, R., Moghadam, M.A., 2015. Discharge Coefficient and Energy Dissipation over Stepped Spillway under Skimming Flow Regime. KSCE J. Civ. Eng. 19, 11741182. https://doi.org/10.1007/s12205-013-0749-3

Sorensen, R.M., 1985. Stepped Spillway Hydraulic Model Investigation. J. Hydraul. Eng. 111, 14611472. https://doi.org/10.1061/(asce)0733-9429(1985)111:12(1461)

Tabbara, M., Chatila, J., Awwad, R., 2005. Computational simulation of flow over stepped spillways. Comput. Struct. 83, 2215-2224. https://doi.org/10.1016/j.compstruc.2005.04.005

Zare, H.K., Doering, J.C., 2012a. Effect of rounding edges of stepped spillways on the flow characteristics. Can. J. Civ. Eng. 39, 140-153. https://doi.org/10.1139/L11-121

Zare, H.K., Doering, J.C., 2012b. Inception Point of Air Entrainment and Training Wall Characteristics of Baffles and Sills on Stepped Spillways. J. Hydraul. Eng. 138, 11191124. https://doi.org/10.1061/(asce)hy.1943-7900.0000630 